\title{
Impact of cloudiness on net ecosystem exchange of carbon dioxide in different types of forest ecosystems in China
}

\author{
M. Zhang ${ }^{1,2}$, G.-R. Yu' ${ }^{1}$, L.-M. Zhang ${ }^{1}$, X.-M. Sun ${ }^{1}$, X.-F. Wen ${ }^{1}$, S.-J. Han ${ }^{3}$, and J.-H. Yan ${ }^{4}$ \\ ${ }^{1}$ Institute of Geographic Sciences and Natural Resources Research, Chinese Academy of Sciences, Beijing, 100101, China \\ ${ }^{2}$ Graduate University of the Chinese Academy of Sciences, Beijing, 100039, China \\ ${ }^{3}$ Institute of Applied Ecology, Chinese Academy of Sciences, Shenyang, 110016, China \\ ${ }^{4}$ South China Botanical Garden, Chinese Academy of Sciences, Guangzhou, 510650, China
}

Received: 2 June 2009 - Published in Biogeosciences Discuss.: 14 August 2009

Revised: 8 February 2010 - Accepted: 9 February 2010 - Published: 23 February 2010

\begin{abstract}
Clouds can significantly affect carbon exchange process between forest ecosystems and the atmosphere by influencing the quantity and quality of solar radiation received by ecosystem's surface and other environmental factors. In this study, we analyzed the effects of cloudiness on net ecosystem exchange of carbon dioxide (NEE) in a temperate broad-leaved Korean pine mixed forest at Changbaishan (CBS) and a subtropical evergreen broad-leaved forest at Dinghushan (DHS), based on the flux data obtained during June-August from 2003 to 2006 . The results showed that the response of NEE of forest ecosystems to photosynthetically active radiation (PAR) differed under clear skies and cloudy skies. Compared with clear skies, the light-saturated maximum photosynthetic rate $\left(P_{\mathrm{ec}, \max }\right)$ at CBS under cloudy skies during mid-growing season (from June to August) increased by 34\%, 25\%, 4\% and 11\% in 2003, 2004, 2005 and 2006, respectively. In contrast, $P_{\mathrm{ec}, \max }$ of the forest ecosystem at DHS was higher under clear skies than under cloudy skies from 2004 to 2006 . When the clearness index $\left(k_{t}\right)$ ranged between 0.4 and 0.6 , the NEE reached its maximum at both CBS and DHS. However, the NEE decreased more dramatically at CBS than at DHS when $k_{t}$ exceeded 0.6. The results indicate that cloudy sky conditions are beneficial to net carbon uptake in the temperate forest ecosystem and the subtropical forest ecosystem. Under clear skies, vapor pressure deficit (VPD) and air temperature increased due to strong light. These environmental conditions led to greater decrease in gross ecosystem photosynthesis (GEP) and greater increase in ecosystem respiration $\left(R_{\mathrm{e}}\right)$ at $\mathrm{CBS}$ than at DHS. As a result, clear sky conditions caused more reduction of NEE in the temperate forest ecosystem than in the subtropical forest ecosystem. The response of NEE of
\end{abstract}

Correspondence to: G.-R. Yu

(yugr@igsnrr.ac.cn) different forest ecosystems to the changes in cloudiness is an important factor that should be included in evaluating regional carbon budgets under climate change conditions.

\section{Introduction}

Solar radiation, temperature and moisture are the main environmental factors that control carbon dioxide exchange between terrestrial ecosystems and the atmosphere (Law et al., 2002; Baldocchi, 2008). Changes in cloudiness and atmospheric aerosols content can directly influence solar radiation and direct and diffuse radiation received on the ground (Gu et al., 2003; Niyogi et al., 2004; Min, 2005). Correspondingly, other environmental variables (temperature, vapor pressure deficit (VPD), etc.) can also change (Gu et al., 1999; Urban et al, 2007). Changes in these environmental variables can strongly affect carbon exchange between terrestrial ecosystems and the atmosphere (Letts et al., 2005; Urban et al., 2007). Many studies have shown that increase in diffuse radiation received by ecosystem's surface can significantly enhance net ecosystem exchange of carbon dioxide (NEE) (Goulden et al., 1997; Gu et al., 1999, 2003; Law et al., 2002) and light use efficiency (LUE) of forest ecosystems (Gu et al., 2002; Alton et al., 2007; Farquhar and Roderick, 2008). Global warming has altered spatial patterns of precipitation and cloudiness on a global scale (Rind et al., 1990; Kirschbaum and Fischlin, 1995). Meanwhile, volcanic eruptions and air pollution have changed atmospheric aerosol content (Niyogi et al., 2007; Farquhar and Roderick, 2008). These changes in cloudiness and atmospheric aerosol content will likely affect the carbon sink function of terrestrial ecosystems in the future.

Published by Copernicus Publications on behalf of the European Geosciences Union. 
Annual precipitation has decreased in North and Northeast China and increased in the mid and lower Yangtze River basin since the 1990's (Wang et al., 2004; Ding et al., 2006) as a result of global climate change. The changes in precipitation patterns decrease cloudiness in North and Northeast China but increase cloudiness in the southern Yangtze River region. These Changes can influence many environmental factors, including solar radiation received on the ground, temperature, and moisture. How these changes affect the carbon uptake of forest ecosystems in different regions of China warrants in-depth study (Yu et al., 2003, 2008).

Ranging from cold temperate zone to subtropical zone, the North-South Transect of Eastern China (NSTEC) embraces a vegetation sequence, starting with cold temperate coniferous forests and extending through temperate mixed forests, warm temperate deciduous broadleaf forests, subtropical evergreen coniferous forests, evergreen broadleaf forests, and tropical rainforests (Yu et al., 2006, 2008). Carbon storage by these forest ecosystems plays an important role in regional and global carbon cycles (Fang et al., 2001; Yu et al., 2008). The temperate broad-leaved Korean pine forest at Changbaishan (CBS) and the subtropical evergreen broad-leaved forest at Dinghushan (DHS) are located within the NSTEC and are parts of ChinaFLUX. These two forest types represent China's north temperate natural forest ecosystem and south subtropical natural forest ecosystem, respectively. The two forests at CBS and DHS are old-growth forests, but they are still acting as strong carbon sink. The annual average values of net ecosystem productivity (NEP) (from 2003 to 2005) at CBS and at DHS were $259 \pm 19$ and $434 \pm 66 \mathrm{~g} \mathrm{C} \mathrm{m}^{-2} \mathrm{yr}^{-1}$, respectively (Yu et al., 2008).

Previous studies have shown that environmental factors controlling carbon exchange were different at CBS and at DHS (Guan et al., 2006; Wang, et al., 2006; Zhang et al., 2006; Yu et al., 2008). Solar radiation received by ecosystem and temperature are the main factors influencing the carbon budget of the temperate forest ecosystem at CBS (Zhang et al., 2006; Yu et al., 2008). Solar radiation received by ecosystem represents the primary factor influencing daytime $\mathrm{CO}_{2}$ flux at CBS during the growing season (Guan et al., 2006). However, solar radiation received by ecosystem was insufficient at DHS due to heavy precipitation in rainy season (summer). As a result, net carbon uptake of this subtropical forest ecosystem reached its highest value at the beginning of dry season (autumn) (Zhang et al., 2006; Yu et al., 2008; Wang et al., 2006).

Not only climate characteristics but also environmental factors controlling carbon exchange were different between the forest ecosystems at CBS and at DHS. Thus, changes in NEE with cloudiness may be different in the two forest ecosystems. During summer, solar radiation received by ecosystem was strong, and temperature reached maximum in the temperate forest ecosystem. Under clear skies, strong solar radiation received by ecosystem and high temperature caused photosynthesis to reach its saturation or even decrease in the temperate forest ecosystem (Guan et al., 2006; Zhang 2006). Meanwhile, these conditions increase ecosystem respiration. Therefore, net carbon uptake of the temperate forest decreased. According to these results, we assume that cloudy skies might benefit the net carbon uptake of the temperate forest ecosystems in summer, as both solar radiation received by ecosystem and temperature relatively decreased. In contrast, temperature and moisture of the subtropical forest ecosystem reached their maximum in summer, but solar radiation received by ecosystem was insufficient because of heavy precipitation and increased cloudiness. Thus, we assume that the high temperature and moisture could increase ecosystem respiration under cloudy sky conditions, but insufficient solar radiation received by ecosystem could restrain photosynthesis. Therefore, net carbon uptake of the subtropical forest would decrease. However, clear skies might benefit to net carbon uptake of the subtropical forest ecosystem in summer, because solar radiation received by ecosystem increased under clear sky conditions. Based on these assumptions, when the environmental factors changed with the pattern of precipitation and cloudiness in China, changes in net carbon uptake of the two forest ecosystems would be different.

In this study, our main objective was to reveal the effects of changes in cloudiness on net carbon uptake of the temperate forest ecosystem at CBS and the subtropical forest ecosystem at DHS in East China. We hypothesized that cloudy skies are more beneficial to increase net carbon uptake in the temperate forest ecosystem at CBS than in the subtropical forest ecosystem at DHS. Our findings can improve the evaluation on the net carbon uptake of different forest ecosystem in the Asia monsoon region under climate change conditions.

\section{Methods}

\subsection{Site description and measurements}

The temperate broad-leaved Korean pine forest at Changbaishan (CBS) is located in China's Jinlin Province $\left(41^{\circ} 41^{\prime} 49^{\prime \prime}-42^{\circ} 25^{\prime} 18^{\prime \prime} \mathrm{N}, 12^{\circ} 42^{\prime} 55^{\prime \prime}-128^{\circ} 16^{\prime} 48^{\prime \prime} \mathrm{E}\right)$. CBS belongs to the monsoon-influenced, temperate continental climate, and its growing season extends from May to September. The subtropical evergreen broad-leaved forest at Dinghushan (DHS) is located in China's Guangdong Province $\left(23^{\circ} 09^{\prime}-23^{\circ} 11^{\prime} \mathrm{N}, 112^{\circ} 30^{\prime}-112^{\circ} 33^{\prime} \mathrm{E}\right)$. DHS belongs to the subtropical monsoon humid climate. Rainfall in DHS reflects a distinct pattern of wet season (from April to September) and dry season (from October to March). Table 1 provides extensive descriptions of the two sites (Guan et al., 2006; Zhang et al., 2006; Yu et al., 2008).

$\mathrm{CO}_{2}$ flux over the two forest ecosystems has been measured with eddy covariance (EC) systems since 2002. The EC system consists of an open-path infrared gas analyzer (Model LI-7500, LICOR Inc., Lincoln, NE, USA) and a 3-D 
Table 1. Site information.

\begin{tabular}{|c|c|c|}
\hline Sites & CBS & DHS \\
\hline Location & $42^{\circ} 24^{\prime} \mathrm{N}, 128^{\circ} 05^{\prime} \mathrm{E}$ & $23^{\circ} 10^{\prime} \mathrm{N}, 112^{\circ} 34^{\prime} \mathrm{E}$ \\
\hline Elevation (m) & 738 & 300 \\
\hline Topography & Flat & Hilly \\
\hline Mean annual temperature $\left({ }^{\circ} \mathrm{C}\right)$ & 3.6 & 20.9 \\
\hline Annual precipitation (mm) & 695 & 1956 \\
\hline Soil type & $\begin{array}{l}\text { Montane dark brown forest } \\
\text { soil }\end{array}$ & $\begin{array}{l}\text { Lateritic red soil, yellow } \\
\text { soil }\end{array}$ \\
\hline Canopy height (m) & 26 & 17 \\
\hline Predominant species & $\begin{array}{l}\text { Pinus koriaensis, Tilia } \\
\text { amurensis, Quercus } \\
\text { mongolica, Fraxinus } \\
\text { mandshurica, Acer mino }\end{array}$ & $\begin{array}{l}\text { Castanopis chinensis, } \\
\text { Schim asuperba, Pinus } \\
\text { massonian }\end{array}$ \\
\hline Leaf area index (LAI) & $\begin{array}{l}6.1 \text { (the maximum in the } \\
\text { growing season) }\end{array}$ & 4.0 (average) \\
\hline Biomass $\left(\mathrm{kg} \mathrm{m}^{-2}\right)$ & 36.23 & 14.14 \\
\hline $\begin{array}{l}\text { Soil organic matter } \\
\left(\mathrm{g} \mathrm{kg}^{-1}\right)^{\mathrm{b}}\end{array}$ & 87.5 & 37.7 \\
\hline Stand age (year) & 200 & 100 \\
\hline Height of Tower (m) & 61.8 & 36 \\
\hline $\begin{array}{l}\text { Height of eddy covariance } \\
\text { system }(m)^{\mathrm{a}}\end{array}$ & 41.5 & 27 \\
\hline Height of radiometer $(\mathrm{m})^{\mathrm{a}}$ & 32 & 36 \\
\hline Height of rain gauge $(\mathrm{m})^{\mathrm{a}}$ & 61.8 & 36 \\
\hline $\begin{array}{l}\text { Profiles of air temperature } \\
\text { and humidity }(\mathrm{m})^{\mathrm{a}}\end{array}$ & $2.5,8,22,26,32,50,60$ & $4,9,15,21,27,31,36$ \\
\hline $\begin{array}{l}\text { Depth of Soil temperature } \\
(\mathrm{cm})^{\mathrm{a}}\end{array}$ & $5,10,20,50,100$ & $5,10,20,50,100$ \\
\hline $\begin{array}{l}\text { Depth of Soil moisture } \\
(\mathrm{cm})^{\mathrm{a}}\end{array}$ & $5,20,50$ & $5,20,40$ \\
\hline
\end{tabular}

${ }^{\text {a}}$ Height and depth indicate the location of the sensors mounted.

${ }^{b}$ Data source: database of Chinese Ecosystem Research Network (CERN)

sonic anemometer (Model CSAT3, Campbell Scientific Inc., Logan, UT, USA). The instrument signals were recorded at $10 \mathrm{~Hz}$ by a CR5000 datalogger (Model CR5000, Campbell Scientific Inc.) and then block-averaged over 30-min intervals for analysis and archiving. Routine meteorological variables were measured simultaneously with the eddy fluxes. Air humidity and air temperature profiles were measured with shielded and aspirated probes (HMP45C, Vaisala, Helsinki, Finland) at different heights above and within the canopy. Global radiation and net radiation above the canopy were measured with radiometers (CM11 and CNR-1, Kipp and Zonen, Delft, The Netherlands). Photosynthetically active radiation (PAR) above the canopy was measured with a quantum sensor (LI-190Sb, LiCor Inc., USA). To ensure the accuracy of the radiation measurement, CM11 and LI190Sb were calibrated and compared with other CM11 and LI-190Sb sensors that were installed at an automatic meteorological observation station of the research station. Precipitation was recorded with a rain gauge (RainGauge 52203,
Young, Traverse City, MI, USA) above the canopy. Soil temperature and soil moisture were measured using thermocouple probes (105T, Campbell, USA, CS616_L, Compbell, USA) and water content reflectometers (CS616, Campbell Scientific Inc), respectively. All meteorological measurements were recorded at 30-min intervals with dataloggers (Model CR10X\&CR23X, Campbell Scientific Inc.) (Guan et al., 2006; Zhang et al., 2006; Yu et al., 2008). Detailed information on the routine meteorological variables is summarized in Table 1.

\subsection{Data processing}

We analyzed the effects of changes in cloudiness on NEE at CBS and at DHS, based on 30-min $\mathrm{CO}_{2}$ flux data and routine meteorological data collected during the growing season (June-August) from 2003 to 2006 . Cloudiness is used in a very general sense referring to the presence, quality, and quantity of clouds in the sky in this study. Because of a lack of continuous measurements of cloudiness at the two 
sites, we used a clearness index $\left(k_{t}\right)$ (Gu et al., 1999) to describe the continuous changes in cloudiness. We analyzed the responses of NEE to PAR under clear and cloudy skies, and examined the relationship between $k_{t}$ and NEE. These methods were simple and direct for evaluating whether changes in cloudiness could affect the NEE of forest ecosystems. These methods have been used in many related studies ( $\mathrm{Gu}$ et al., 1999, 2002; Law et al, 2002; Alton et al., 2007).

\subsubsection{Flux data processing}

We used a program to process raw 30-min flux data as described in the following (1) 3-D coordinate rotation was applied to force the average vertical wind speed to zero and to align the horizontal wind to mean wind direction (Baldocchi et al., 2000; Wilczak et al., 2001), (2) flux data were corrected for the variation of air density caused by transfer of heat and water vapor (Webb et al., 1980), (3) the storage below EC height was calculated by using the temporal change in $\mathrm{CO}_{2}$ concentration above the canopy measured with LI7500 (Carrara et al., 2003), (4) the abnormal data were filtered, and data gaps were filled by using the look-up table method (Falge et al., 2001; Guan et al., 2006; Zhang et al., 2006).

In this study, we only used the data measured during the mid growing season (June-August) from 2003 to 2006 to eliminate the effect of changing leaf area index (LAI). The LAI of CBS was about $5.3 \pm 0.1 \mathrm{~m}^{2} \mathrm{~m}^{-2}$ from June to August over the four years. The broad-leaved forest at DHS is evergreen without significant variation of LAI over and within season. The LAI of DHS was about $4.6 \pm 0.2 \mathrm{~m}^{2} \mathrm{~m}^{-2}$ from June to August over the four years.

\subsubsection{Defining clearness index}

The clearness index $k_{t}$ is defined as the ratio of global solar radiation $\left(S, \mathrm{~W} \mathrm{~m}^{-2}\right)$ received at the Earth's surface to the extraterrestrial irradiance at a plane parallel to the Earth's surface $\left(S_{\mathrm{e}}, \mathrm{W} \mathrm{m}^{-2}\right)$ (Gu et al., 1999):

$k_{t}=\frac{S}{S_{\mathrm{e}}}$,

$S_{\mathrm{e}}=S_{\mathrm{sc}}\left[1+0.033 \cos \left(360 t_{\mathrm{d}} / 365\right)\right] \sin \beta$,

$\sin \beta=\sin \varphi \cdot \sin \delta+\cos \varphi \cdot \cos \delta \cdot \cos \omega$

where $S_{\mathrm{sc}}$ is the solar constant $\left(1370 \mathrm{~W} \mathrm{~m}^{-2}\right), t_{\mathrm{d}}$ is the day of year, $\beta$ is the solar elevation angle, $\phi$ is degree of latitude, $\delta$ is declination of the sun and $\omega$ is time angle. $k_{t}$ reflects not only sky conditions but also the degree of influence of cloudiness on the solar radiation received at the Earth's surface. For a given solar elevation angle, smaller $k_{t}$ indicates increasing in cloud thickness, and larger $k_{t}$ indicates a clearer sky (Gu et al., 1999).

\subsubsection{Defining clear skies}

The rainy season in CBS and DHS extends from June to August, thus days with no clouds through the entire day were rare during this period. We identified the clear mornings and afternoons based on a half-day basis (Gu et al., 1999; Law et al., 2002). Two criteria were established for identifying clear mornings and afternoons. First, $k_{t}$ must increase smoothly with $\sin \beta$. Second, the curve of the relation between the clear-sky $k_{t}$ and $\sin \beta$ must form an envelope in the lumped scatter plot of $k_{t}$ against $\sin \beta$. The following steps were used: (1) clear morning or afternoons were selected if the values of $k_{t}$ changed with time smoothly, (2) values of $k_{t}$ of the selected morning or afternoons were plotted against $\sin \beta$, the mornings or afternoons were excluded if the relation between $k_{t}$ and $\sin \beta$ on those days fell away from the dominant pattern, (3) finally, the clearness index was plotted against $\sin \beta$ for all mornings and afternoons in the growing season to make sure the identified relationship between the clear sky clearness index and $\sin \beta$ formed the envelope for the scatter points on the plots (Gu et al., 1999; Law et al., 2002). Figure 1 shows the relationship between $k_{t}$ and $\sin \beta$ under clear skies, which can be fitted by cubic polynomial (Eq. 4) (Gu et al., 1999). Asymmetry existed between the clear mornings and the clear afternoons (Fig. 1).

$k_{t 0}=a \sin ^{3} \beta+b \sin ^{2} \beta+c \sin \beta+d$

where $k_{t 0}$ is the clear sky clearness index, and $a, b, c$, and $d$ are regression coefficients.

\subsubsection{Defining diffuse PAR}

For a given solar elevation angle, the diffuse components of the solar radiation received by ecosystem could change with cloudiness (Gu et al., 2002; Urban et al., 2007). However, the diffuse PAR was not measured at the two sites. Therefore, we used $k_{t}$ and $\beta$ to calculate diffuse PAR. The corresponding equations are as follows (Reindl et al., 1990; Gu et al., 1999).

$\operatorname{PAR}_{\text {dif }}=\operatorname{PAR} \cdot \frac{\left[1+0.3\left(1-q^{2}\right)\right] q}{1+\left(1-q^{2}\right) \cos ^{2}\left(90^{\circ}-\beta\right) \cos ^{3} \beta}$

$q=\left(S_{\mathrm{f}} / S_{\mathrm{e}}\right) / k_{t}$

Interval: $0 \leq k_{t} \leq 0.3$; Constraint: $S_{\mathrm{f}} / S_{\mathrm{e}} \leq k_{t}$

$S_{\mathrm{f}} / S_{\mathrm{e}}=k_{t}\left[1.020-0.254 k_{t}+0.0123 \sin \beta\right]$

Interval: $0.3<k_{t}<0.78$; Constraint: $0.1 k_{t} \leq S_{\mathrm{f}} / S_{\mathrm{e}} \leq 0.97 k_{t}$

$S_{\mathrm{f}} / S_{\mathrm{e}}=k_{t}\left[1.400-1.749 k_{t}+0.177 \sin \beta\right]$

Interval: $0.78 \leq k_{t}$; Constraint: $0.1 k_{t} \leq S_{\mathrm{f}} / S_{\mathrm{e}}$

$S_{\mathrm{f}} / S_{\mathrm{e}}=k_{t}\left[0.486 k_{t}-0.182 \sin \beta\right]$

where PAR dif $_{\text {if }}$ is the diffuse PAR ( $\mu$ mol quantum $\mathrm{m}^{-2} \mathrm{~s}^{-1}$ ), and $S_{\mathrm{f}}$ denotes the total diffuse radiation received by a horizontal plane on the Earth's surface $\left(\mathrm{W} \mathrm{m}^{-2}\right)$. 


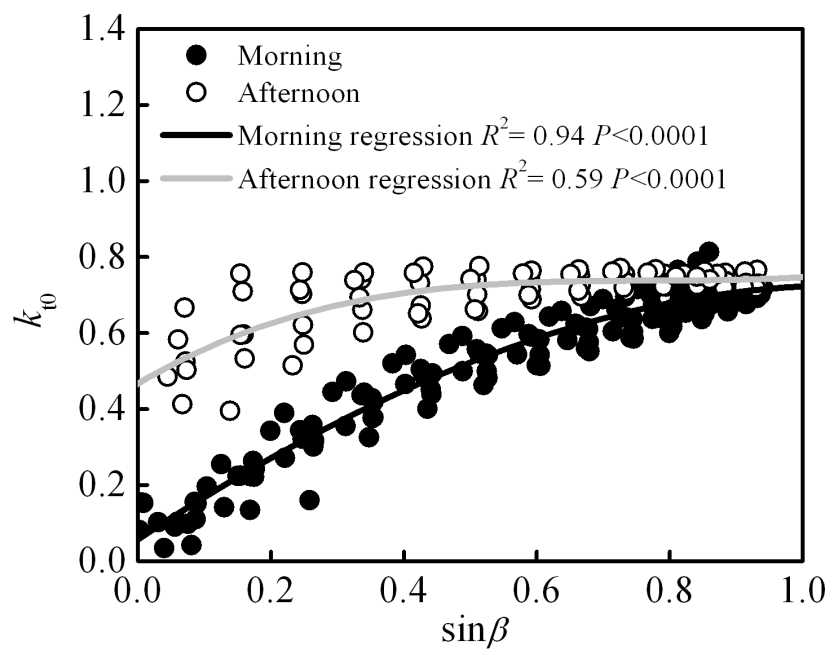

Fig. 1. The relationship between clear sky clearness index $\left(k_{t}\right)$ and sine of solar elevation angles for the CBS site from June to August in 2003.

\subsubsection{The response of NEE to PAR}

The response of NEE to PAR can be described by MichaelisMenten equation (Goulden et al., 1997; Aubinet et al., 2001; Wu et al., 2006; Zhang, 2006):

$\mathrm{NEE}=\frac{\alpha \cdot \mathrm{PAR} \cdot P_{\mathrm{ec}, \max }}{\alpha \cdot \mathrm{PAR}+P_{\mathrm{ec}, \max }}+R_{\mathrm{e}}$,

where $\alpha$ is the ecosystem apparent quantum yield ( $\mathrm{mg} \mathrm{CO} 2 \mu \mathrm{mol}^{-1}$ quantum), $P_{\mathrm{ec}, \max }$ is the light-saturated maximum photosynthetic rate $\left(\mathrm{mgCO}_{2} \mathrm{~m}^{-2} \mathrm{~s}^{-1}\right)$, and $R_{\mathrm{e}}$ is the average daytime ecosystem respiration $\left(\mathrm{mg} \mathrm{CO} \mathrm{m}^{-2} \mathrm{~s}^{-1}\right)$.

\subsubsection{Flux partitioning}

Gross ecosystem photosynthesis (GEP) was calculated using the following equation:

$\mathrm{GEP}=R_{\mathrm{e}}-\mathrm{NEE}$.

NEE was obtained directly from the EC measurement. Ecosystem respiration $\left(R_{\mathrm{e}}\right)$ was estimated using the LloydTaylor equation (Eq. 12) (1994). The nighttime NEE data under turbulent conditions were used to establish $R_{\mathrm{e}^{-}}$ temperature response relationship:

$R_{\mathrm{e}}=R_{\mathrm{ref}} \mathrm{e}^{E_{0}\left(1 /\left(T_{\mathrm{ref}}-T_{0}\right)-1 /\left(T-T_{0}\right)\right)}$

where $T$ is air temperature or soil temperature $\left({ }^{\circ} \mathrm{C}\right)$. For CBS, soil temperature at $5 \mathrm{~cm}$ was used, while air temperature at $4 \mathrm{~m}$ above ground was used for DHS (Yu et al., 2005), for better regressions (i.e. higher $R^{2}$ value) relative to the use of soil temperature (Yu et al., 2005, 2008). In the equation, $R_{\text {ref }}$ represents the ecosystem respiration rate at a reference temperature $\left(T_{\text {ref }}, 10^{\circ} \mathrm{C}\right), E_{0}$ is the parameter that essentially determines the temperature sensitivity of ecosystem respiration and $T_{0}$ is a constant, set at $-46.02{ }^{\circ} \mathrm{C}$. Equation (12) was also used to estimate daytime $R_{\mathrm{e}}$.

In the study, the sign of NEE is negative when $\mathrm{CO}_{2}$ is transported from the atmosphere down to ecosystem and positive for the opposite case. $R_{\mathrm{e}}$ is positive when carbon is released by ecosystem. GEP is positive when carbon is absorbed by ecosystem.

\subsection{Statistic analysis}

The relationship between NEE, GEP, $R_{\mathrm{e}}$ and environmental factors were fitted with linear, and non-linear equations. We conducted all analysis using the Origin package. Statistically significant differences were set with $P<0.05(\alpha=0.05)$ unless otherwise stated.

\section{Results}

\subsection{Seasonal variation of environmental variables}

Figure 2 shows the seasonal variations of the monthly cumulative global solar radiation received by ecosystem $(S)$, mean monthly air temperature $\left(T_{\mathrm{a}}\right.$, near the height of EC system at the two site, $32 \mathrm{~m}$ at CBS, $27 \mathrm{~m}$ at DHS, see Table 1) and monthly cumulative precipitation $(P)$ at CBS and DHS. The seasonal variations of environmental factors in the two forest ecosystems were not exactly the same. The seasonal pattern of $T_{\mathrm{a}}$ was in good agreement with $P$ at CBS (Fig. 2b and c). Maximum $P$ and $T_{\mathrm{a}}$ occurred at the same time. $T_{\mathrm{a}}$ and $P$ at CBS reached their highest value in July. $T_{\mathrm{a}}$ and $P$ were higher at DHS from June to August. However, when $T_{a}$ reached the maximum in July, $P$ was relatively lower (Fig. 2e and $\mathrm{f}$ ). The values of $S$ from June to August were smaller than that in May at CBS due to the effect of precipitation (Fig. 2a). $S$ reached its maximum in July at DHS (Fig. 2d).

Although precipitation was abundant at both ecosystems from June to August, the frequency of $k_{t}$ value fell between 0 and 0.4 was greater at DHS than at CBS (Fig. 3). Furthermore, the total precipitation from June to August was $436.6 \mathrm{~mm}$ at CBS and $768.6 \mathrm{~mm}$ at DHS. These facts indicated that there were more rainy days and fewer clear days at DHS than at CBS during this period. As a result, $S$ was lower at DHS than at CBS from June to August (Fig. 2a and d). The total $S$ was $1610.1 \mathrm{MJ} \mathrm{m}^{-2}$ at CBS and $1356 \mathrm{MJ} \mathrm{m}^{-2}$ at DHS for this period.

\subsection{Responses of NEE to PAR under clear and cloudy skies}

The response of NEE to PAR differed under clear and cloudy skies in the two forest ecosystems (Fig. 4). NEE was more negative under cloudy skies than under clear skies at CBS during the mid growing season (from June to August) 

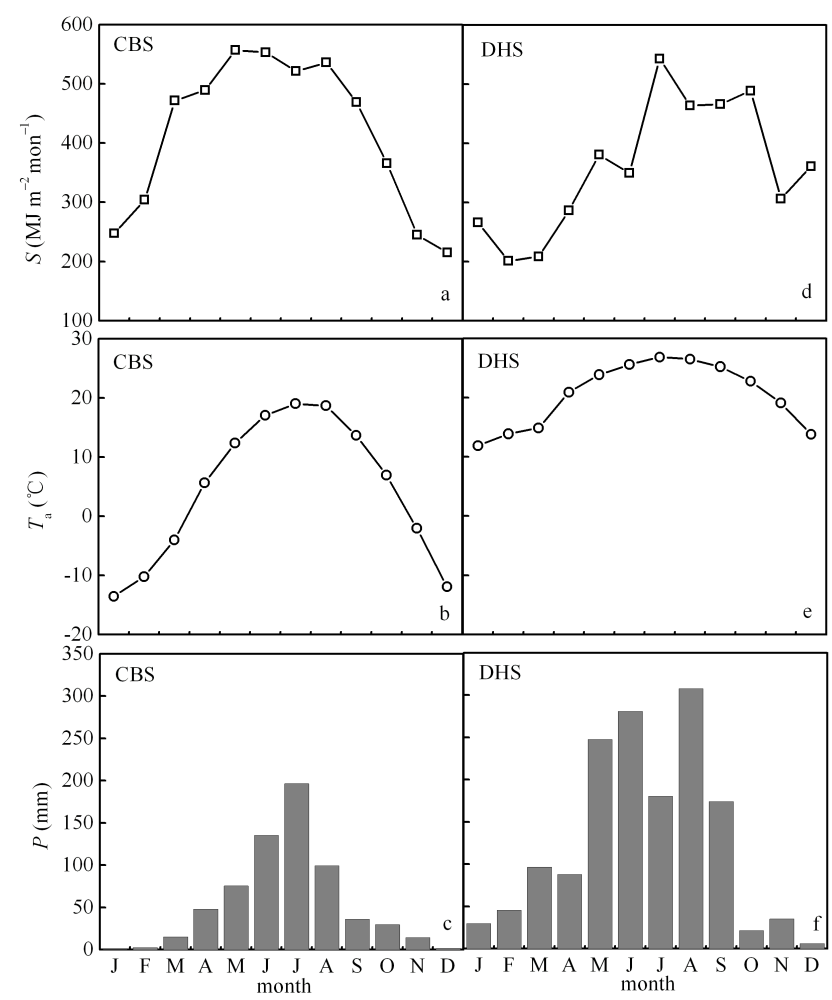

Fig. 2. The seasonal variations of global solar radiation $(S)$, air temperature $\left(T_{\mathrm{a}}\right)$ and precipitation $(P)$ at CBS and DHS.

(Fig. 4a to d). This indicates that the net carbon uptake at CBS increased under cloudy sky conditions. Compared with clear skies, $P_{\mathrm{ec}, \max }$ under cloudy skies at CBS during mid growing season (from June to August) increased by $34 \%$, $25 \%, 4 \%$ and $11 \%$ in 2003, 2004, 2005 and 2006, respectively (Table 2). In contrast, NEE was not more negative under cloudy skies than under clear skies at DHS (Fig. 4e to h). Except for 2003, $P_{\mathrm{ec}, \max }$ at DHS was higher under clear skies than under cloudy skies in the other three years (Table 2). The results indicate that the differences in response of NEE to PAR under cloudy skies and under clear skies were not exactly the same in the two forest ecosystems. Cloudy sky conditions were more beneficial to relieving light saturation and enhancing $P_{\mathrm{ec}, \max }$ in the temperate forest ecosystem at CBS relative to the subtropical forest ecosystem at DHS.

\subsection{Changes in NEE with clearness index}

To further explore the effect of changes in cloudiness on NEE, we analyzed the response of NEE to changes in the clearness index at CBS and at DHS. We grouped the data into $5^{\circ}$ intervals of solar elevation angles to eliminate the effect of solar elevation angle on the responses of NEE to $k_{t}$. We found similar results for the four study years in the two ecosystems. In this paper, we only present the results in 2005.

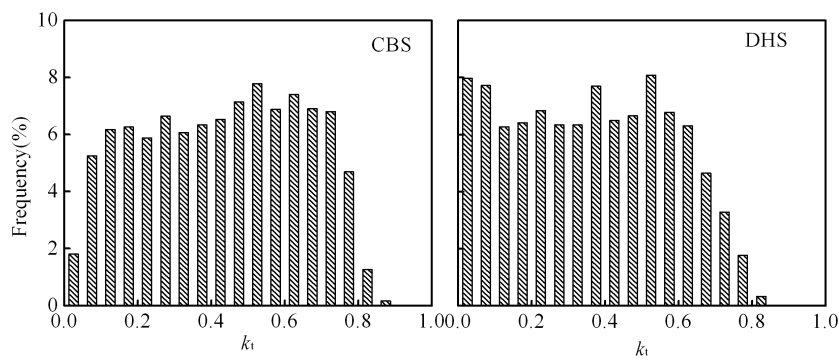

Fig. 3. Histograms of the frequency distribution of the variation of the clearness index $\left(k_{t}\right)$ for solar elevation angles $\beta>20^{\circ}$ at CBS and DHS from June to August in the years from 2003 to 2006.

For different intervals of the solar elevation angle, the changes in NEE with clearness index were conic (the regressional coefficients of this conic equation are shown in Table 3) at both CBS and DHS in the mid growing season (Fig. 5). The NEE reached its maximum when $k_{t}$ fell between 0.4 and 0.6 (Fig. 5) at CBS and at DHS. This result indicates that net carbon uptake of the two forests at CBS and DHS was highest under cloudy skies. The NEE decreased when the value of $k_{t}$ exceeded 0.6 at both CBS and DHS (Fig. 5). However, decrease in NEE was less at DHS than at CBS (Fig. 5). This finding indicates that clear sky conditions restrain net carbon uptake more at CBS than at DHS.

\section{Discussion}

\subsection{Differences in the responses of NEE to cloudiness in different types of forest ecosystems}

The NEE of the forest ecosystems at CBS and at DHS reached its maximum under cloudy skies when the value of $k_{t}$ was between 0.4 and 0.6. This finding is consistent with those of previous studies. These studies show that NEE of forest ecosystems reached its maximum values under cloudy skies when the value of $k_{t}$ is between $0.4-0.7$ ( $\mathrm{Gu}$ et al., 1999; Letts et al., 2005; Urban et al., 2007). However, when the value of $k_{t}$ exceeded 0.6, NEE of the temperate forest at CBS reduced more with increasing $k_{t}$ than that at DHS. This suggests that NEE of the temperate forest at CBS was more sensitive to strong solar radiation under clear sky conditions, compared to the subtropical forest at DHS. Similarly, Alton et al. (2007) found that NEE of boreal forest had the greatest sensitivity to changes in shortwave radiation among a sparse, boreal needle-leaf ecosystem, a temperate broadleaf ecosystem and a dense tropical, broadleaf forest ecosystem. Under cloudy skies, the NEE increased more than $30 \%$ in temperate forest ecosystems (Gu et al., 1999). But, the NEE increased less than $25 \%$ under cloudy skies in the forest ecosystems in Amazonia (Oliveira et al., 2007). These findings suggest that the net carbon uptake increases more in temperate forests than in subtropical forests under cloudy sky conditions. 
Table 2. Parameter values of light response curve of CBS and DHS on clear skies and cloudy skies from June to August in the years from 2003 to 2006.

\begin{tabular}{|c|c|c|c|c|c|c|c|c|c|}
\hline \multirow[t]{2}{*}{ Site } & \multirow[t]{2}{*}{ Parameter values } & \multicolumn{2}{|c|}{2003} & \multicolumn{2}{|c|}{2004} & \multicolumn{2}{|c|}{2005} & \multicolumn{2}{|c|}{2006} \\
\hline & & $\begin{array}{l}\text { Cloudy } \\
\text { skies }\end{array}$ & $\begin{array}{l}\text { Clear } \\
\text { skies }\end{array}$ & $\begin{array}{l}\text { Cloudy } \\
\text { skies }\end{array}$ & $\begin{array}{l}\text { Clear } \\
\text { skies }\end{array}$ & $\begin{array}{l}\text { Cloudy } \\
\text { skies }\end{array}$ & $\begin{array}{l}\text { Clear } \\
\text { skies }\end{array}$ & $\begin{array}{l}\text { Cloudy } \\
\text { skies }\end{array}$ & $\begin{array}{l}\text { Clear } \\
\text { skies }\end{array}$ \\
\hline \multirow{6}{*}{ CBS } & $\alpha$ & & & & & & & & \\
\hline & (mg CO $2 \mu \mathrm{mol}^{-1}$ quantum) & -0.0036 & -0.0027 & -0.0037 & -0.0041 & -0.0039 & -0.0032 & -0.0039 & -0.0044 \\
\hline & $P_{\mathrm{ec}, \max }$ & -1309 & -0864 & -1210 & -0.902 & -1307 & -1253 & -1213 & -1079 \\
\hline & $R_{\mathrm{e}}$ & 1.007 & T.0. & 1.210 & 0.50 & 1.00 & 1.200 & 1.25 & 1.07 \\
\hline & $\left(\mathrm{mg} \mathrm{CO}_{2} \mathrm{~m}^{-2} \mathrm{~s}^{-1}\right)$ & 0.281 & 0.217 & 0.278 & 0.257 & 0.244 & 0.369 & 0.244 & 0.337 \\
\hline & $R^{2}$ & 0.67 & 0.50 & 0.55 & 0.50 & 0.60 & 0.66 & 0.62 & 0.56 \\
\hline \multirow{5}{*}{ DHS } & $\alpha$ & & & & & & & & \\
\hline & (mg CO $2 \mu \mathrm{mol}^{-1}$ quantum) & -0.0012 & -0.0019 & -0.0011 & -0.0009 & -0.0012 & -0.0007 & -0.0012 & -0.0008 \\
\hline & $\begin{array}{c}P_{\mathrm{ec}, \max } \\
\left(\mathrm{mg} \mathrm{CO}_{2} \mathrm{~m}^{-2} \mathrm{~s}^{-1}\right) \\
R_{\mathrm{e}}\end{array}$ & -0.682 & -0.647 & -0.839 & -1.208 & -0.81 & -0.946 & -0.9362 & -1.155 \\
\hline & $\left(\mathrm{mg} \mathrm{CO}_{2} \mathrm{~m}^{-2} \mathrm{~s}^{-1}\right)$ & 0.116 & 0.129 & 0.106 & 0.095 & 0.051 & 0.084 & 0.081 & 0.08 \\
\hline & $R^{2}$ & 0.50 & 0.39 & 0.44 & 0.59 & 0.45 & 0.54 & 0.52 & 0.50 \\
\hline
\end{tabular}

\subsection{The effects of changes in cloudiness on environmental factors in the two types of forest ecosystems}

Environmental conditions influence the carbon exchanged process between forest ecosystems and the atmosphere. For a given solar elevation angle interval, when the sky conditions changed from clear to cloudy, total solar radiation received by ecosystem decreased, and balance of diffuse and direct components of solar radiation received by ecosystem changed as well. Correspondingly, other environmental factors $\left(T_{\mathrm{a}}, \mathrm{VPD}\right.$, etc.) also changed. Finally, these changes can influence carbon exchange process between forest ecosystem and the atmosphere.

During cloudy days, the increase in diffuse radiation received by ecosystem was more easily absorbed by shaded leaves for photosynthesis in forest canopy with higher leaf area index (LAI) (Gu et al., 2002; Alton et al., 2007; Farquhar and Roderick, 2008). Therefore, increased diffuse radiation received by ecosystem is used more efficiently for canopy photosynthesis under cloudy skies. When $k_{t}$ was between 0.4 and 0.6 , diffuse PAR received by ecosystem reached its maximum at CBS and DHS (Fig. 6a and b). This range of $k_{t}$ was the same as the range of $k_{t}$ that caused NEE to reach its peak. This indicates that photosynthesis of the two forest ecosystems at CBS and at DHS can increase with increasing diffuse PAR received by ecosystem under cloudy skies.

VPD is an important factor affecting stomatal conductance. A decrease in VPD induces stomatal openness and thus enhances leaf photosynthesis (Collatz et al., 1998).
Table 3. Regressional Coefficients of the conic equation NEE $=a$ $k_{t}^{2}+b k_{t}+c$ for CBS and DHS in 2005 .

\begin{tabular}{cccccc}
\hline & $\beta$ & $a$ & $b$ & $c$ & $R^{2}$ \\
\hline CBS & $35-40^{\circ}$ & 3.68 & -3.71 & 0.22 & 0.45 \\
& $45-50^{\circ}$ & 3.59 & -3.63 & 0.14 & 0.46 \\
& $55-60^{\circ}$ & 3.61 & -3.65 & 0.08 & 0.42 \\
& $65-70^{\circ}$ & 3.64 & -3.81 & 0.09 & 0.40 \\
\hline DHS & $55-60^{\circ}$ & 2.05 & -2.08 & 0.09 & 0.50 \\
& $65-70^{\circ}$ & 1.45 & -1.71 & 1.45 & 0.44 \\
& $75-80^{\circ}$ & 1.32 & -1.48 & -0.04 & 0.28 \\
& $85-90^{\circ}$ & 1.98 & -2.02 & 0.05 & 0.51 \\
\hline
\end{tabular}

Therefore, the decrease in VPD associated with cloudy conditions can enhance canopy photosynthesis (Freeman et al., 1998). CBS and DHS are located at different latitude, thus the interval of change in solar elevation angles differs at the two sites. Furthermore, the similar results were found in different intervals of solar elevation angles. Thus, we only present the results of higher interval of solar elevation angles at the two sites (the reason was the same for the following similar analyses). Figure $6 \mathrm{c}$ shows that VPD decreased linearly with decreasing $k_{t}$ for selected intervals of solar elevation angles at CBS and DHS. Our results suggest that the decrease in VPD under cloudy skies can enhance photosynthesis in the two forest ecosystems at CBS and at DHS. 


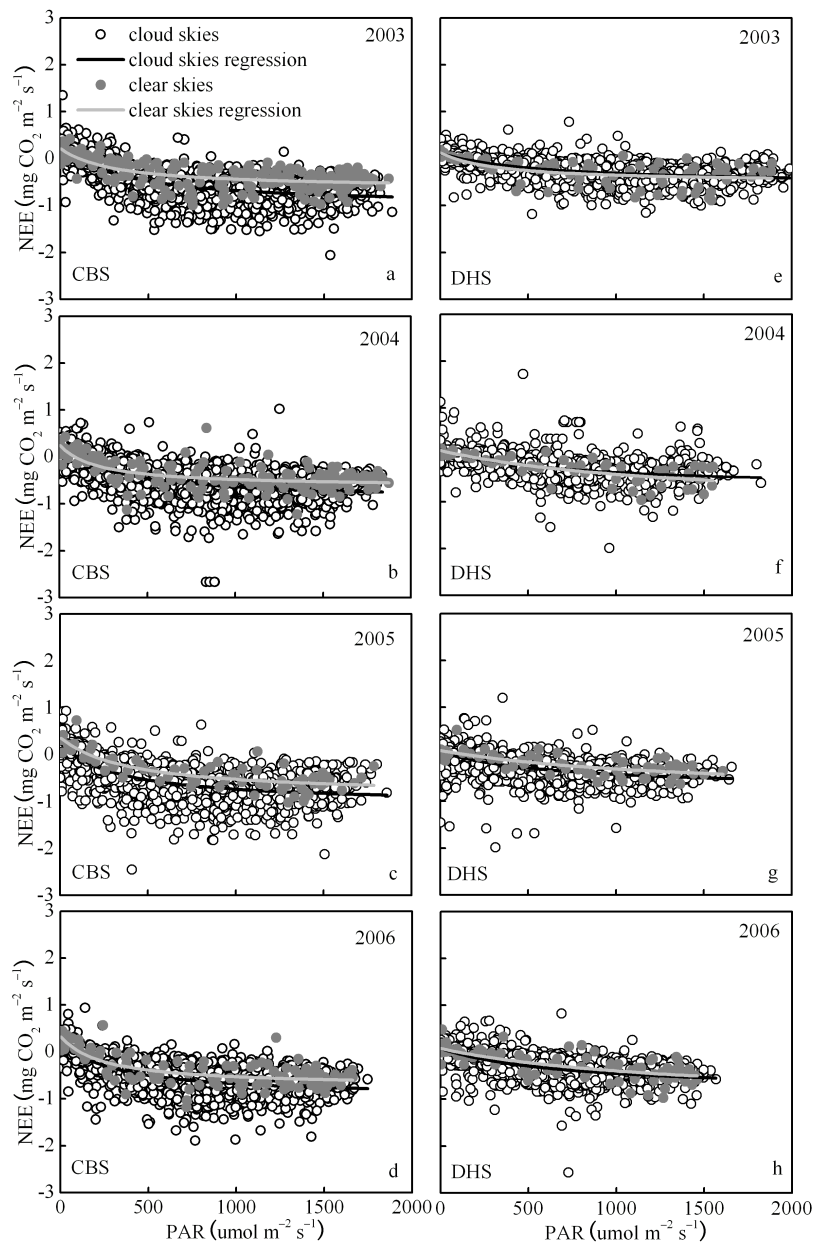

Fig. 4. Light response curves of the forests at (a-d) CBS and (e-h) DHS on clear skies and cloud skies from June to August in the years from 2003 to 2006 .

Temperature is a controlling factor in ecosystem respiration processes. $T_{\mathrm{a}}$ decreased linearly with decreasing $k_{t}$ for selected intervals of solar elevation angles at DHS and CBS (Fig. 6d). This indicates that a decrease in air temperature could cause a decrease in ecosystem respiration at the two sites.

The increase of diffuse PAR and the decrease of VPD and $T_{\mathrm{a}}$ under cloudy skies can be beneficial to increase in ecosystem photosynthesis and decrease in ecosystem respiration of the two forest ecosystems at CBS and at DHS. Thus, cloudy sky conditions can increase net carbon uptake of the two forest ecosystems.

\subsection{Environmental control on GEP and $R_{\mathrm{e}}$ in the two types of forest ecosystems}

NEE tended to reach its maximum at both CBS and DHS under cloudy skies, but NEE decreased more dramatically at CBS than at DHS under clear skies. This phenomenon relates to the different influences of environmental factors on
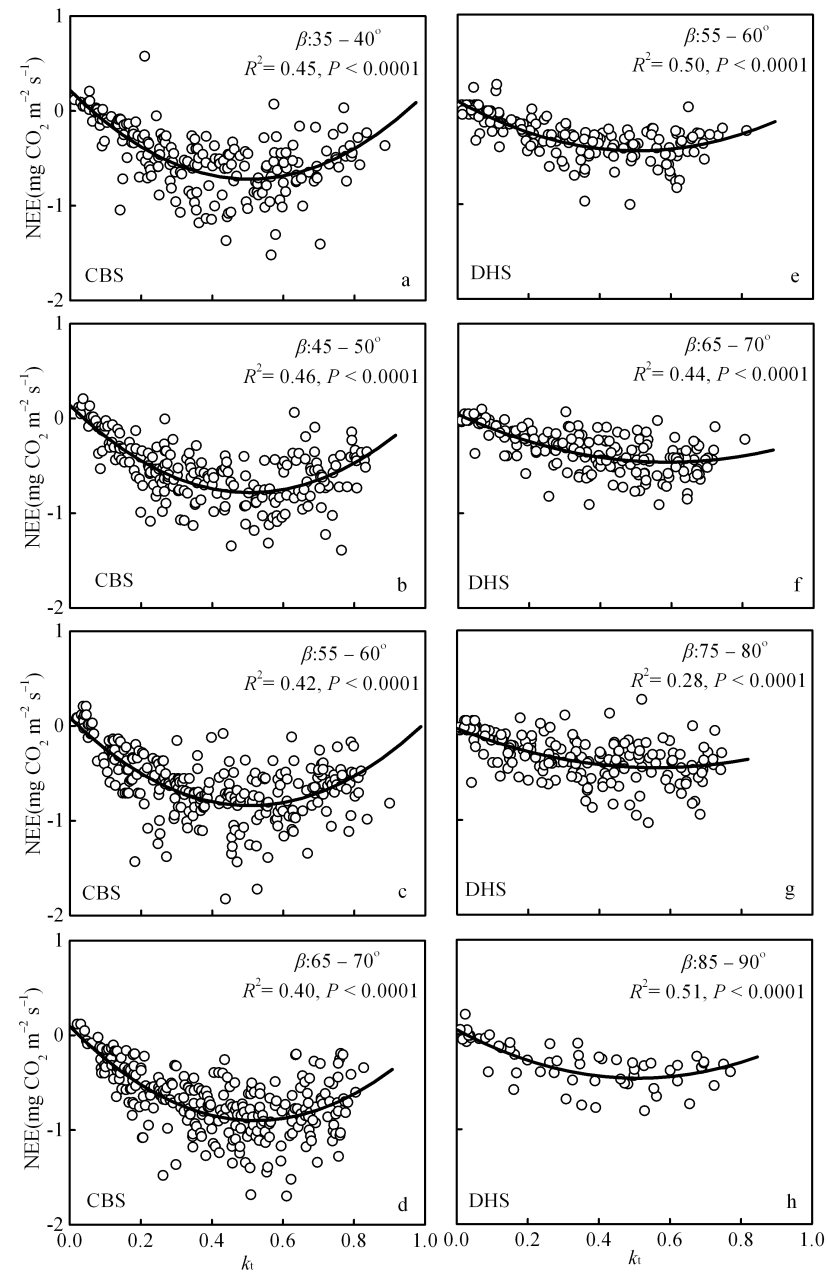

Fig. 5. Relationship between NEE and the clearness index $\left(k_{t}\right)$ at CBS and DHS for different intervals of solar elevation angles from June to August in 2005.

GEP and $R_{\mathrm{e}}$ in the two ecosystems. Furthermore, differences in climate characteristics and differences in composition and structure of vegetation can cause different influences of environmental factors on GEP and $R_{\mathrm{e}}$ in the two forest ecosystems. Thus, changes in NEE under clear sky conditions will be different at CBS and at DHS.

Changes in quality and quantity of solar radiation received by ecosystem with varying sky conditions can influence ecosystem photosynthesis. The solar radiation received by ecosystem was stronger at CBS than at DHS from June to August (Fig. 2a and d). Therefore, the response of ecosystem photosynthesis to PAR may be different at CBS and at DHS, especially under stronger PAR conditions. For a given solar elevation angle interval, the highest PAR exceeded $1500 \mu \mathrm{mol}$ quantum $\mathrm{m}^{-2} \mathrm{~s}^{-1}$ at $\mathrm{CBS}$, but the highest PAR at DHS was about $1500 \mu \mathrm{mol}$ quantum $\mathrm{m}^{-2} \mathrm{~s}^{-1}$ (Fig. 7a). The stronger PAR condition more easily caused light saturation to limit ecosystem photosynthesis at CBS than at DHS. 

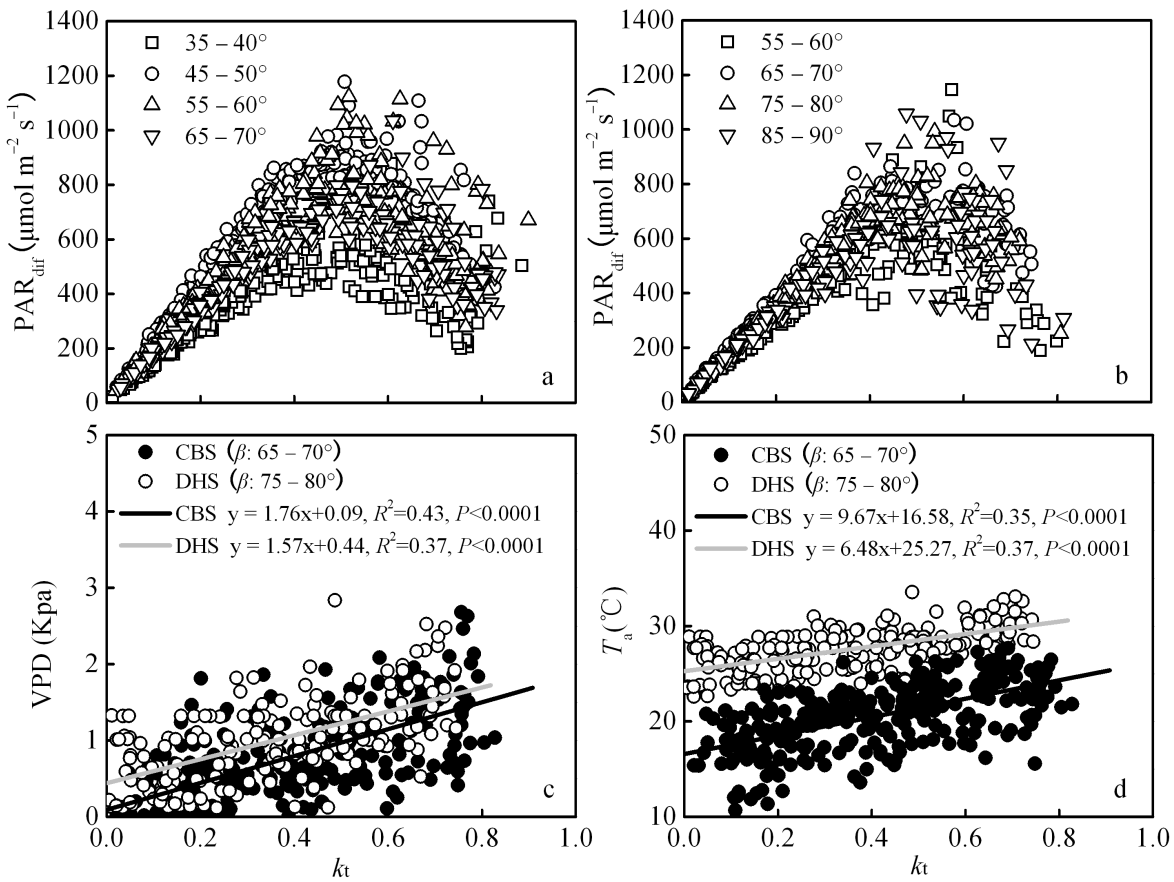

Fig. 6. Changes of diffuse PAR (PAR $\left.\mathrm{dif}_{\mathrm{fi}}\right)$ at (a) CBS, (b) DHS, (c) air temperature $\left(T_{\mathrm{a}}\right)$ and (d) vapor pressure deficit (VPD) with the clearness index $\left(k_{t}\right)$ for selected intervals of solar elevation angles from June to August in 2005.
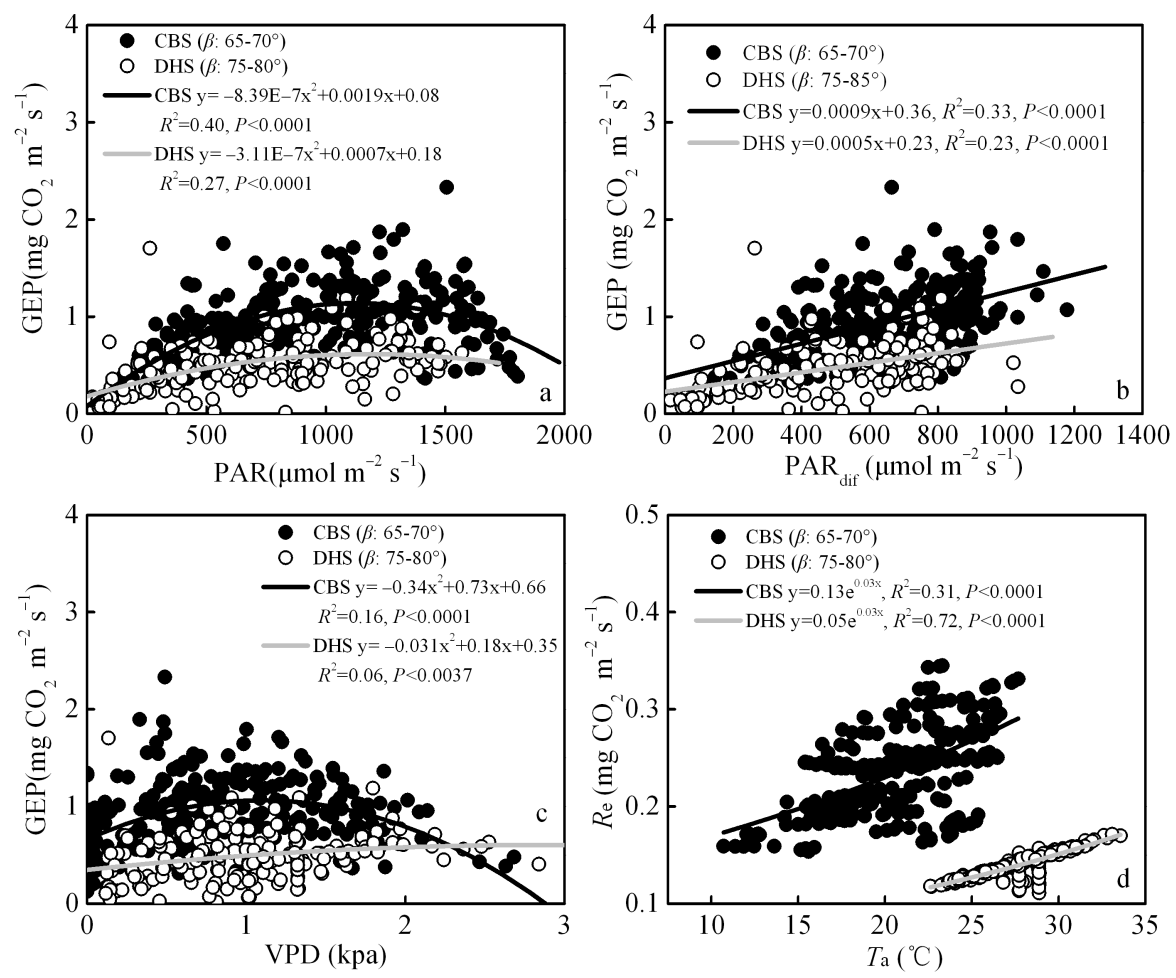

Fig. 7. Changes of GEP with (a) PAR, (b) diffuse PAR (PAR dif $)$ and (c) vapor pressure deficit (VPD) and Changes of (d) $R_{\mathrm{e}}$ with air temperate $\left(T_{\mathrm{a}}\right)$ for selected intervals of solar elevation angles at CBS and DHS from June to August in 2005. 
When PAR exceeded $1500 \mu$ mol quantum $\mathrm{m}^{-2} \mathrm{~s}^{-1}$, the GEP decreased more at CBS than at DHS. Changes in incoming diffuse radiation with changes in cloudiness are one of important factors that influence forest ecosystem photosynthesis (Gu et al., 2002; Urban et al., 2007). For a given solar elevation angle interval, the GEP increased linearly with the diffuse PAR received by the ecosystems at CBS and at DHS from June to August (Fig. 7b). But the GEP increased more at CBS than at DHS (Fig. 7b). This result might be due to the effect of different LAI and canopy structure on the photosynthesis in the two ecosystems. LAI and biomass was greater at CBS than at DHS from June to August (Table 1) resulted in greater canopy density at CBS. Therefore, increased diffuse PAR was more beneficial to GEP at CBS than at DHS.

Changes in VPD under different sky conditions can affect GEP of forest ecosystems. For a given solar elevation angle interval, the changes in GEP with VPD were conic at CBS and DHS from June to August (Fig. 7c). When VPD exceeded $1.5 \mathrm{kpa}$, GEP reduced with increasing VPD at CBS (Fig. 7c). However, GEP reduced with increasing VPD at DHS only when VPD exceeded $2.0 \mathrm{kpa}$. Overall, the reduction was less at DHS than at CBS (Fig. 7c). Therefore, increase in VPD under clear skies decreased GEP more at CBS than at DHS.

Changes in temperature can influence forest ecosystem respiration. For a given solar elevation angle interval, the $R_{\mathrm{e}}$ at CBS and at DHS varied exponentially with temperature (Fig. 7d). The increased rate of $R_{\mathrm{e}}$ with temperature was larger at CBS than at DHS (Fig. 7d), because the $R_{\mathrm{e}}$ of the temperate forest at CBS exhibited higher temperature sensitivity than that at DHS (Yu et al., 2008). Furthermore, temperature sensitivity (i.e., $Q_{10}$ ) of soil respiration was higher at CBS than at DHS (Zheng et al., 2009), because soil organic matter content is greater at CBS than at DHS (Table 1). Higher content of soil organic matter and higher $Q_{10}$ leads to greater potential for soil $\mathrm{CO}_{2}$ efflux (Knorr et al., 2005; Zheng et al., 2009). Furthermore, soil respiration is major component of $R_{\mathrm{e}}$. Therefore, as temperature increased, $R_{\mathrm{e}}$ increased more at CBS than at DHS.

In generally, increase in total PAR, decrease in diffuse PAR received by ecosystem, and higher VPD under clear skies led to greater decrease in GEP at CBS than at DHS. Higher temperature under clear skies caused greater increase in $R_{\mathrm{e}}$ at CBS than at DHS. As a result, the NEE decreased more at CBS than at DHS under clear skies. This suggests that clear sky conditions are more detrimental to net carbon uptake in the temperate forest than in the subtropical forest.

\section{Conclusions}

Similar to most forest ecosystems in the Northern Hemisphere, forest ecosystems in East China has more net carbon uptake under cloudy sky conditions. When the clearness index was between $0.4-0.6$, the environmental factors were optimal to make NEE reach its highest level in the temperate as well as subtropical forests. However, stronger solar radiation and higher VPD and air temperature under clear skies cause a greater decrease in GEP and a greater increase in $R_{\mathrm{e}}$ in the temperate forest than in the subtropical forest. Therefore, under clear skies, the NEE decrease more dramatically in the temperate forest than in the subtropical forest. Clear sky conditions restrain net carbon uptake more in the temperate forest than in the subtropical forest. Our results imply that, as a consequence of global climate change, the decrease in cloudiness over Northeast China would have a significant impact on net carbon uptake of temperate forest ecosystems.

Acknowledgements. This research was supported by Asia 3 Foresight Program (30721140307), the National Key Research and Development Program (2010CB833500), National Natural Science Foundation of China (Project No. 30590381), the "Hundred Talents" Program of the Chinese Academy of Sciences and the Knowledge Innovation Project of the Chinese Academy of Sciences (KZCX2-YW-432), National Natural Science Foundation of China (Grant No. 30900198). We acknowledge the researchers at CBS and DHS sites for providing data. We gratefully acknowledge the anonymous reviewers for their constructive comments, which were very helpful for the improvement of on our manuscript. Special thanks are due to David C. Brill (from Institute for a Secure and Sustainable Environment, The University of Tennessee) for his revisions on language expressions.

Edited by: J. Chen

\section{References}

Alton, P. B., North, P. R., and Los, S. O.: The impact of diffuse sunlight on canopy light-use efficiency gross photosynthetic product and net ecosystem exchange in three forest biomes, Global Change Biol., 13, 1-12, 2007.

Aubinet, M., Chermanne, B., Vandenhaute, M., Longdoz, B., Yernaux, M., and Laitat, E.: Long term carbon dioxide exchange above a mixed forest in the Belgian Ardennes, Agr. For. Meteorol., 108, 293-315, 2001.

Baldocchi, D., Finnigan, J., Wilson, K., Paw U, K. T., and Falge, E.: On measuring net ecosystem carbon exchange over tall vegetation on complex terrain, Bound-Lay. Meteorol., 96, 257-291, 2000.

Baldocchi, D.: "Breathing" of the terrestrial biosphere: lessons learned from a global network of carbon dioxide flux measurement systems, Aust. J. Bot., 56, 1-26, 2008.

Carrara, A., Kowalski, A. S., Neirynck, J., Janssens, I. A., Curiel Yuste, J., Ceulemans, R.: Net ecosystem $\mathrm{CO}_{2}$ exchange of mixed forest in Belgium over 5 years, Agr. For. Meteorol., 119, 209227, 2003.

Collatz, G. J., Ball, J. T., Grivet, C., and Berry, J. A.: Physiological and environmental regulation of stomatal conductance, photosynthesis and transpiration: A model that includes a laminar boundary layer, Agric. For. Meteorol., 54, 107-136, 1991

Ding, Y. H., Ren, G. Y., Shi, G. Y., Gong, P., Zheng, X. H., Zhai, P. M., Zhang, D. E., Zhao, Z. C., Wang, S. W., Wang, H. J., Luo, 
Y., Chen, D. L., Gao, X. J., and Dai, X. S.: National assessment report of climate change (I): Climate change in China and the future trend, Adv. Climate Change Res., 2(1), 3-8, 2006.

Falge, E., Baldocchi, D., Olson, R., Anthoni, P., Aubinet, M., Bernhofer, C., Burba, G., Ceulemans, R., Clement, R., Dolman, H., Granier, A., Gross, P., Grünwald, T., Hollinger, D., Jensen, N. O., Katul, G., Keronen, P., Kowalski, A., Lai, C. T., Law, B. E., Meyers, T., Moncrieff, J., Moors, E., Munger, J. W., Pilegaard, K., Rannik, Ü., Rebmann, C., Suyker, A., Tenhunen, J., Tu, K., Verma, S., Vesala, T., Wilson, K., and Wofsy, S.: Gap filling strategies for defensible annual sums of net ecosystem exchange, Agr. For. Meteorol., 107, 43-69, 2001.

Fang, J. Y., Chen, A. P., Peng, C. H., Zhao, S. Q., and Ci, L. J.: Changes in forest biomass carbon storage in China between 1949 and 1998, Science, 292, 2320-2322, 2001.

Farquhar, G. D. and Roderick, M. L.: Pinatubo, diffuse light, and carbon cycle, Science, 299, 1997-1998, 2008.

Freedman, J. M., Fitzjarrald, D. R., Moore, K. E., and Sakai, R. K.: Boundary layer cloud climatology and enhanced forestatmosphere exchange, in Preprints of 23rd Conference on Agricultural and Forest Meteorology, 41-44, Am. Meteorol. Soc., Boston, Mass., 1998.

Gilmanov, T. G., Soussana, J. F., Aires, L., Allard, V., Ammann, C., Balzarolo, M., Barcza, Z., Bernhofer, C., Campbell, C. L., Cernusca, A., Cescatti, A., Brown, C. J., Dirks, B. O. M., Dore, S., Eugster, W., Fuhrer, J., Gimeno, C., Gruenwald, Haszpra, L., Hensen, A., Ibrom, A., Jacobs, A. F. G., Jones, M. B., Lanigan, G., Laurila, T., Lohila, A., Manca, G., Marcolla, B., Nagy, Z., Pilegaard, K., Pinter, K., Pio, C., Raschi, A., Rogiers, N., Sanz, M. J., Stefani, P., Sutton, M., Tuba, Z., Valentini, R., Williams, M. L., and Wohlfahrt, G.: Partitioning European grassland net ecosystem $\mathrm{CO}_{2}$ exchange into gross primary productivity and ecosystem respiration using light response function analysis, Agri. Ecosys. Environ., 121, 93-120, 2007.

Goulden, M. L., Daube, B. C., Fan, S. M., Sutton, D. J., Bazzaz, A., Munger, J. W., and Wofsy, S.: Physiological responses of a black spruce forest to weather, J. Geophys. Res., 102, 28987-28996, 1997.

Gu, L. H., Baldocchi, D. D., Verma, S. B., Black, T. A., Vesala, T., Falge, E., and Dowty, P. R.: Advantages of diffuse radiation for terrestrial ecosystem productivity, J. Geophys. Res., 107(D6), 4050, doi:10.1029/2001JD001242, 2002.

Gu, L. H., Baldocchi, D. D., Wofsy, S. C., Michalsky, J., Urbanski, S., and Boden, T.: Response of a deciduous forest to the Mount Pinatubo eruption: Enhanced photosynthesis, Science, 299, 2035-2038, 2003.

Gu, L. H., Fuentes, J. D., and Shugart, H. H.: Responses of net ecosystem exchanges of carbon dioxide to changes in cloudiness: Results from two North American deciduous forests, J. Geophys. Res., 104, 31421-31434, 1999.

Guan, D. X., Wu, J. B., Zhao, X. S., Han. S. J., Yu, G. R., Sun, X. M., and Jin, C. J.: $\mathrm{CO}_{2}$ fluxes over an old, temperate mixed forest in northeastern China, Agr. For. Meteorol., 137, 138-149, 2006.

Kirschbaum, M. U. F. and Fischlin, A.: Climate Change Impacts on Forests, in: Climate Change 1995: Impacts Adaptations And Mitigation Of Climate Change: Scientific Technical Analysis, edited by: Watson, R. T., Zinyowera, M. C., and Moss, R. H., Cambridge University Press, New York, USA, 95-129, 1996.
Knorr, W., Prentice, I. C., House, J. I., and Holland, E. A.: Longterm sensitivity of soil carbon turnover to warming, Nature 433, 298-301, 2005.

Law, B. E., Falge, E., Gu, L. H., Baldocchi, D., Pakwin, P., Berbigier, P., Davis, K., Dolman, A. J., Falk, M., Fuentes, J. D., Goldstein, A., Granier, A., Grelle, A., Hollinger, D., Janssens, I. A., Jarvis, P., Jensen, N. O., Katul, G., Mahli, Y., Matteucci, G., Meyers, T., Monson, R., Munger, W., Oechel, W., Olson, R., Pilegaard, K., Paw, K. T., Thorgeirsson, H., Valentini, R., Verma, S., Vesala, T., Wilson, K., and Wofsy, S.: Environmental controls over carbon dioxide and water vapor exchange of terrestrial vegetation, Agr. For. Meteorol., 113, 97-120, 2002.

Letts, M. G. and Lafleur P. M.: On the relationship between cloudiness and net ecosystem carbon dioxide exchange in a peatland ecosystem, Ecoscience, 12(1), 53-59, 2005.

Leuning, R.: A critical appraisal of a combined stomatalphotosynthesis model for C3 plant, Plant Cell Environ., 18, 339355, 1995.

Lloyd, J. and Taylor, J. A.: On the temperature dependence of soil respiration, Func. Ecol., 8, 315-323, 1994.

Min, Q. L.: Impacts of aerosols and clouds on forestatmosphere carbon exchange, J. Geophys. Res., 110, D06203, doi:10.1029/2004JD004858, 2005.

Niyogi, D., Chang, H., Chen, F., Gu, L. H., Kumar, A., Menon, S., and Pielke, R. A.: Potential impacts of aerosol-land-atmosphere interactions on the Indian monsoonal rainfall characteristics, Nat. Hazards, 42, 345-359, 2007.

Niyogi, D., Chang, H., Saxena, V. K., Holt, T., Alapaty, K., Booker, F., Chen, F., Davis, K. J., Holben, B., Matsui, T., Meyers, T., Oechel, W. C., Pielke, R. A., Well, R., Wilson, K., and Xue, Y. K.: Direct observations of the effects of aerosol loading on net ecosystem $\mathrm{CO}_{2}$ exchanges over different landscapes, Geophys. Res. Lett., 31, L20506, doi:10.1029/2004GL020915, 2004.

Oliveira, P. H. F., Artaxo, P., Pires, C., Lucca, S. D., Procópio, A., Holben, B., Schafer, J., Cardoso, L. F., Wofsy, S. C., Rocha, H. R.: The effects of biomass burning aerosols and clouds on the $\mathrm{CO}_{2}$ flux in Amazonia, Tellus, 59B, 338-349, 2007.

Reichstein, M., Fagle, E., Baldocchi, D., Palale, D., Aubinet, M., Berbigier, P., Bernhofer, C., Buchmann, N., Gilmanov, T., Granier, A., Grünwald, T., Havrànkovà, K., Ilvesniemi, H., Janous, D., Knohl, A., Laurila, T., Lohila, A., Loustau, D., Matteucci, G., Meyers, T., Migiletta, F., Ourcival, J. M., Pumpaney, J., Rambal, S., Rotenberg, E., Sanz, M., Tenhunen, J., Seufert, G., Vaccari, F., Vesala, T., Yakir, D., and Valentini, R.: On the separation of net ecosystem exchange into assimilation and ecosystem respiration: review and improved algorithm, Glob. Change Biol., 11, 1424-1439, 2005.

Reindl, D. T., Beckman, W. A., and Duffie, J. A.: Diffuse fraction correlation, Sol. Ener., 45, 1-7, 1990.

Rind, D., Goldberg, R., Hansen, J., Rosenzweig, C., and Ruedy, R.: Potential evapotranspiration and the likelihood of future drought, J. Geophys. Res., 95(D7), 9983-10004, 1990.

Urban, O., Janouš, D., Acosta, M., Czerný, R., Marková, I., Navrátil, M., Pavelka, M., Pokorný, R., Šprtová, M., Zhang, R., Špunda, V., Grace, J., and Marek, M. V.: Ecophysiological controls over the net ecosystem exchange of mountain spruce stand. Comparison of the response in direct vs. diffuse solar radiation, Glob. Change Biol., 13, 157-168, 2007.

Wang, Z. Y., Ding, Y. H., He, J. H., and Lu, J.: An updating analysis 
of the climate change in China in recent 50 years, Acta Meteorol Sin., 62(2), 228-236, 2004.

Webb, E. K., Pearman, G. I., and Leuning, R.: Correction of flux measurement for density effects due to heat and water vapor transfer, Q. J. R. Meteorol. Soc., 106, 85-100, 1980.

Wilczak, J. M., Oncley, S. P., and Stage, S. A.: Sonic anemometer tilt correction algorithms, Bound.-Lay. Meteorol., 99, 127-150, 2001.

Wu, J. B., Guan, D. X., Sun, X. M., Zhang, M., Shi, T. T., Han, S. J., and Jin, C. J.: Photosynthetic characteristics of dominant tree species and canopy in the broadleaved Korean pine forest of Changbai Mountains, Sci. China Ser. D: Earth Sci., 36 (Suppl. I), 83-90, 2006.

Yu, G. R., Wen, X. F., Li, Q. K., Zhang, L. M., Ren, C. Y., Liu Y. F., and Guan, D. X.: Seasonal patterns and environmental control of ecosystem respiration in subtropical and temperate forests in China, Sci. China Ser. D: Earth Sci., 48 (Suppl. I), 93-105, 2005.

Yu, G. R., Zhang, L. M., Sun X. M., Fu, Y. L., Wen, X. F., Wang, Q. F., Li, S. G., Ren, C. Y., Song, X., Liu, Y. F., Han, S. J., and Yan, J. H.: Environmental controls over carbon exchange of three forest ecosystems in eastern China, Glob. Change Biol., 14, 2555-2571, 2008.
Zhang, L. M.: Ecophysiological controls on seasonal variations of ecosystem carbon exchange of typical forest ecosystems along NSTEC. PhD dissertation, Institute of Geographic Sciences and Natural Resources Research, the Chinese Academy of Sciences, Beijing, 119-133, 2006(in Chinese with English abstract).

Zhang, L. M., Yu, G. R., Sun, X. M., Wen, X. F., Ren, C. Y., Song, X., Liu, Y. F., Guan, D. X., Yan, J. H., and Zhang, Y. P.: Seasonal variation of carbon exchange of typical forest ecosystems along the eastern forest transect in China, Sci. China Ser. D: Earth Sci., 36 (Suppl. I), 4559, 2006.

Zheng, Z. M., Yu, G. R., Fu, Y. L., Wang, Y. S., Sun, X. M., and Wang, Y. H.: Temperature sensitivity of soil respiration is affected by prevailing climatic conditions and soil organic carbon content: A trans-China based case study, Soil Biol. Biochem., 41, 1531-1540, 2009. 